\title{
Comparison of the Propofol-Remifentanil and Desflurane-Remifentanil in Target-Controlled Infusion
}

\author{
(ㄷ) Özlem Sezen, (1) Gülten Arslan
}

\section{Department of Anesthesiology and Reanimation, University of Health Sciences, Kartal Dr. Lütfi Kırdar Training and Research Hospital, İstanbul, Turkey}

Submitted: 06.04.2020 Accepted: 17.04.2020

Correspondence: Özlem Sezen, Sağlık Bilimleri Üniversitesi Karta Dr. Lütfi Kırdar Eğitim ve Araştırma Hastanesi, Anesteziyoloji ve Reanimasyon Kliniği, İstanbul, Turkey E-mail: drozlemsezen@hotmail.com

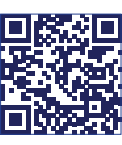

Keywords: Bispectral index; desflurane; propofol; remifentanil; targetcontrolled infusion.

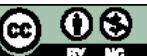

\begin{abstract}
Objective: Our objective was to examine the clinical properties of two anesthetic regimens, propofol-remifentanil target-controlled infusion ( $\mathrm{TCl}$ ) or desflurane-remifentanil $\mathrm{TCl}$ under bispectral index (BIS) guidance during lower abdominal surgery procedures.

Methods: Sixty consenting patients who scheduled for lower abdominal surgery were prospectively studied and were included in one of the two groups: propofol-remifentanil group (Group P) or desflurane-remifentanil group (Group D). General anaesthesia was induced with $2 \mathrm{mg} \mathrm{kg}{ }^{-1}$ propofol, $\mathrm{l} \mu \mathrm{kg}^{-1}$ remifentanil and $0.6 \mathrm{mg} \mathrm{kg}^{-1}$ rocuronium injection. After intubation, remifentanil was administered using the $\mathrm{TCl}$ device in both groups. The pharmacokinetic model of Minto was used. Group D patients received a 50\%-50\% oxygenair mixture and $6 \%$ desflurane. The Schnider model was selected for the administration of propofol $1 \%(10 \mathrm{mg} / \mathrm{mL})$ in Group P, and the TCl dose was adjusted to $4 / \mathrm{mL}^{-1}$. The propofol infusion and inspired fraction of desflurane were adjusted to keep BIS value between 40-60. Hemodynamic parameters, time until recovery of spontaneous respiration, eye-opening and tracheal extubation, compliance with verbal commands, duration of anesthesia and surgery and postoperative modified Aldrete scores were recorded for all patients.
\end{abstract}

Results: The heart rate $(p=0.006)$, diastolic arterial pressure $(p=0.003)$ and mean arterial pressure $(p<0.000 I)$ for the Group $P$ was significantly higher than Group $D$. The extubation time was shorter in Group $P(p=0.02)$, but there was no significant difference between the groups concerning other recovery findings.

Conclusion: BIS-guided combinations of propofol-remifentanil and desflurane-remifentanil delivered using $\mathrm{TCl}$ are both suitable for patients undergoing lower abdominal surgery. The low blood pressure achieved with target-controlled infusions of remifentanil and desflurane may confer important advantages.

\section{INTRODUCTION}

Total intravenous anesthesia (TIVA) is a common method used today as an alternative to inhalation anesthesia. The loss of consciousness and analgesia provided by general anesthesia can be achieved with the use of volatile or intravenous (iv) anesthetics and opioids. ${ }^{[1]}$

In the application of general anesthesia, inhalation agents can be controlled by monitoring the minimal anesthetic concentration, but until recently, there was no alternative objective method available for TIVA, except measuring the plasma level of drugs. Target-controlled infusion (TCl) systems are like vaporizers and now provide this option for TIVA. ${ }^{[2,3]}$

$\mathrm{TCl}$ is a general anesthesia method to achieve and maintain the desired target concentration of iv anesthetic agents at a specific plasma level or site of action. This technique provides a better titration of anesthetic drugs estimated at approximately $30 \%$ by considering the individual pharmacokinetic and pharmacodynamic differences of each sequential dose applied. ${ }^{[4,5]}$ This infusion technique converts a predetermined target concentration to the amount of drug to be administered with a syringe infusion pump per unit time. This conversion is performed automatically by a microchip that is programmed by an algorithm that uses a pharmacokinetic model of the drug to be dispensed in the pump.

$\mathrm{TCl}$ systems are pumps that will deliver the required blood concentration of a drug as a bolus and subsequent infusion according to calculated pharmacokinetic models. ${ }^{[6]}$

In our study, the TCl technique and bispectral index (BIS)guided monitoring was used to administer desflurane or 
propofol in combination with remifentanil, a short-acting opioid, in patients undergoing lower abdominal surgery. A comparison of the peroperative hemodynamic effects, recovery characteristics and postoperative side effects in the two groups was made.

\section{MATERIALS AND METHODS}

After approval of the local ethics committee of our hospital (decision no: 20/8/5/4/I28/15 date: 24.4.20/8), 60 patients with American Society of Anesthesiologists (ASA) classification of physical condition I or II; without anemia, or cardiac, pulmonary, or neuromuscular diseases, or known drug, egg, soybean oil allergy; non-obese (body mass index <25) and who were to undergo elective abdominal surgery other than thoracic or upper abdominal surgery were included in the study. The patients were premedicated with iv midazolam at a dose of $0.02 \mathrm{mg} / \mathrm{kg}$.

The adductor pollicis brevis muscle nerve was monitored with a neuromuscular junction monitor (TOF-Watch SX; Organon, Dublin, Ireland) to observe the effect of the muscle relaxant before extubation of the patients. Heart rate $(H R)$, noninvasive blood pressure, and peripheral oxygen saturation $\left(\mathrm{SpO}_{2}\right)$ were measured in the DIl derivation of an electrocardiogram. BIS values were monitored using the BIS Quatro sensor electrode (Medtronic, Inc., Minneapolis, MN, USA) placed on the forehead and monitored with the Aspect electroencephalogram monitor (A-2000 BIS XP Platform; Aspect Medical Systems, Inc., Norwood, MA, USA).

Endotracheal intubation was performed after induction of anesthesia with $2 \mathrm{mg} \mathrm{kg}^{-1}$ propofol $\left(10 \mathrm{mg} \mathrm{sec} \mathrm{se}^{-1}\right), \mathrm{I} \mu \mathrm{g} \mathrm{kg}$ remifentanil (within $30-60 \mathrm{sec}$ ) and $0.6 \mathrm{mg} \mathrm{kg}^{-1}$ rocuronium iv.

For maintenance of anesthesia, a syringe containing remifentanil $\left(50 \mu \mathrm{mL}^{-1}\right)$ was mounted on an Injectomat TIVA target-controlled infusion device (Agilia Intuitive Generation; Fresenius Health Care Group, Bad Homburg, Germany) and the infusion dose was adjusted according to the Minto pharmacokinetic model. Remifentanil was administered at a plasma concentration of $3 \mathrm{ng} \mathrm{mL}-1$.

In Group D, a combination of $50 \%-50 \%$ oxygen-air mixture and $6 \%$ desflurane was delivered. The desflurane concentration was increased or decreased by $1 \%$ to maintain a BIS value between 40-60.

Desflurane and remifentanil infusions were discontinued at the conclusion of surgery and the arousal time of the patients was recorded.

In Group P, the Schnider pharmacokinetic model was selected for the administration of propofol $1 \%(10 \mathrm{mg} / \mathrm{mL})$, and the starting dose was $4 \mu / \mathrm{mL}^{-1}$ and increased or decreased by $0.5 \mu \mathrm{L}^{-1}$ to keep the BIS value between $40-60$.

The hemodynamic parameters of all of the patients were recorded before induction, after induction and after intubation. In addition, it was recorded every 10 minutes until the end of the surgery.

The time until the recovery of spontaneous breathing, eye-opening, tracheal extubation, response to verbal commands (hand shaking), and the duration of anesthesia and surgery were recorded. After extubation, a modified Aldrete scoring system was used in the recovery room at 0,5 , and 30 minutes. Patients who experienced nausea and vomiting were administered iv $10 \mathrm{mg}$ metoclopramide hydrochloride when necessary. An HR below 50 beats/minute was accepted as bradycardia, and $0.015 \mathrm{mg}$ atropine was administered. If the (mean arterial pressure) MAP was below $20 \%$ of the baseline value, hypotension was evaluated and fluid replacement or $5 \mathrm{mg}$ iv ephedrine was administered, according to the patient's condition.

The demographic characteristics and collected data of the patients were analyzed using IBM SPSS Statistics for Windows, Version 25.0 (IBM Corp., Armonk, NY, USA). Qualitative variables were described using mean, maximum and minimum, and percentage values. Variables with a normal distribution were reported as mean $\pm S D$. Student's t-test was used for comparisons between groups. Pearson's chisquare test and Fisher's exact test were used for further analysis. The median and intermittent distribution of nonparametric continuous variables were recorded and compared using the Mann-Whitney $U$ test. $P<0.05$ was considered statistically significant.

\section{RESULTS}

Since this study had a prospective design, a power analysis was performed before initiation. The study group was selected from a total of 92 patients treated over a two years period (population size). G*Power software (G*Power 3.1.9.2 for Windows 10; Erdfelder, Faul, and Buchner, University of Dusseldorf, Dusseldorf, Germany) was used to calculate the desired sample size. To achieve a confidence level of $95 \%$, an alpha level of $5 \%$, the margin of error of $5 \%$, and a large effect size $(=0.50), 31$ patients were required for each group, a total of 62 cases for this study. The program available at https://www.randomizer. org/ (G.C. Urbaniak and S. Plous) was used, and patients were randomized into two groups. ${ }^{[7]}$

One patient from each group subsequently elected to withdraw from this study; therefore, the results of $30 \mathrm{pa}-$ tients in each group were evaluated in this study.

Of the 60 patients, the mean age was $48.3 \pm 10.3$ years. In all, 45 were female $(75 \%)$, and 15 were male $(25 \%)$. The characteristics of the patients and the distribution in the two groups are shown in Table 1 .

There was no statistically significant difference between the groups concerning age, weight, duration of the anesthesia or operation time; however, differences in gender, height, and ASA score were detected (Table I).

Examination of hemodynamic values measured before and after induction and following intubation, no intergroup difference was observed in the HR, systolic blood pressure, 
Table I. Demographic characteristics (mean \pm SD)

\begin{tabular}{lcccc}
\hline Variables & Total & Group P (n=30) & Group D (n=30) & p-value \\
\hline Age (years) & $48.3 \pm 10.3$ & $48.2 \pm 10.3$ & $48.5 \pm 10.6$ & 0.912 \\
Male (male/female \%) & $15 / 45$ & $12 / 18$ & $3 / 27$ & 0.01 \\
Height (cm) & $162.7 \pm 7.6$ & $165.1 \pm 9.2$ & $160.4 \pm 4.6$ & 0.01 \\
Weight (kg) & $74.6 \pm 11.9$ & $74.9 \pm 10.0$ & $74.4 \pm 13.7$ & 0.864 \\
ASA status (n) (I/II) & $20 / 40$ & $6 / 24$ & $14 / 16$ & 0.02 \\
Duration of the anesthesia (min) & $53.2 \pm 12.9$ & $52.1 \pm 12.7$ & $54.3 \pm 13.2$ & 0.520 \\
Duration of the procedure (min) & $42.8 \pm 12.6$ & $41.8 \pm 12.4$ & $43.8 \pm 12.9$ & 0.544 \\
\hline
\end{tabular}

${ }^{*} \mathrm{p}<0.05$ significant. SD: Standard deviation; ASA: American Society of Anesthesiologists.

Table 2. Clinical data related to the patient groups

\begin{tabular}{|c|c|c|c|}
\hline Variables (min) & Group P & Group D & $\mathbf{p}$ \\
\hline \multicolumn{4}{|l|}{ HR (bpm) } \\
\hline 5 & $86.2 \pm 16.6$ & $86.0 \pm 12.7$ & NA \\
\hline 10 & $83.0 \pm 16.5$ & $81.2 \pm 11.5$ & 0.847 \\
\hline 20 & $78.1 \pm 13.5$ & $73.6 \pm 11.7$ & 0.198 \\
\hline 30 & $77.8 \pm 12.4$ & $73.6 \pm 11.7$ & 0.08 \\
\hline 40 & $77.7 \pm 12.5$ & $73.9 \pm 12.3$ & 0.285 \\
\hline 50 & $78.0 \pm 13.6$ & $73.7 \pm 14.9$ & 0.335 \\
\hline 60 & $81.8 \pm 16.2$ & $72.1 \pm 17.1$ & 0.166 \\
\hline 70 & $83.5 \pm 18.8$ & $71.0 \pm 15.6$ & 0.310 \\
\hline \multicolumn{4}{|l|}{ MAP (mmHg) } \\
\hline 5 & $91.5 \pm 21.8$ & $86.2 \pm 15.9$ & 0.293 \\
\hline 10 & $91.5 \pm 19.3$ & $84.0 \pm 16.3$ & 0.09 \\
\hline 20 & $100.9 \pm 17.2$ & $83.8 \pm 16.1$ & $<0.001^{*}$ \\
\hline 30 & $97.1 \pm 16.0$ & $88.4 \pm 20.6$ & $0.05^{*}$ \\
\hline 40 & $97.9 \pm 14.5$ & $86.1 \pm 20.0$ & $0.01^{*}$ \\
\hline 50 & $99.1 \pm 13.9$ & $100.5 \pm 12.2$ & $0.004^{*}$ \\
\hline 60 & $100.5 \pm 12.2$ & $88.1 \pm 19.8$ & $0.08^{*}$ \\
\hline 70 & $97.5 \pm 12.3$ & $89.1 \pm 12.0$ & 0.264 \\
\hline
\end{tabular}

diastolic blood pressure (DAP), mean arterial pressure (MAP), SpO2, or BIS values.

During the operation, it was observed that HR $(p=0.006)$, $\operatorname{DAP}(p=0.003)$, and MAP $(p<0.000 \mathrm{I})$ findings were significantly higher in Group P, while the SAP in Group P was high and close to significance $(p=0.07)$ (Table 2) (Fig. I, 2).

$\mathrm{SpO}_{2}$ and $\mathrm{BIS}$ values were similar between groups.

A statistically significant intergroup difference between the groups was observed in the length of time until extubation: The mean extubation time was $4.9 \pm 1.0$ minutes in Group P while it was $5.4 \pm 0.8$ minutes in Group $D(p=0.02)$. However, there was no significant difference between the groups concerning time to onset of spontaneous breathing, eye-opening, or compliance with verbal commands. There was no significant difference between the groups in the Aldrete score estimated at 0,5 , and 30 minutes. At the end of the $30^{\text {th }}$ minute, more patients achieved an

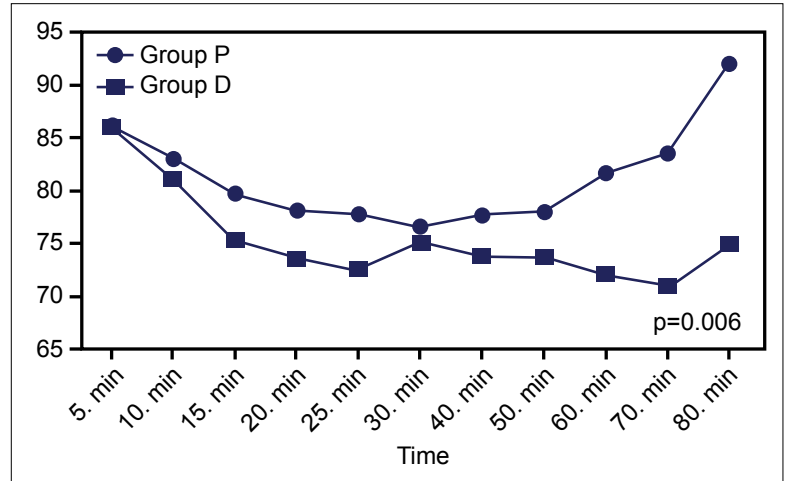

Figure 1. Intragroup variations in intraoperative peak heart rate.

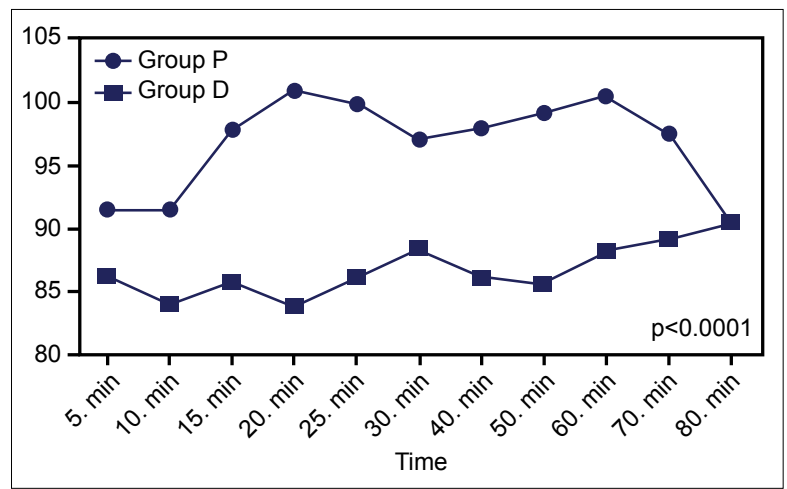

Figure 2. Intragroup variations in intraoperative mean arterial pressure value.

Aldrete score of 10 points in Group D, but the intergroup difference was not significant $(p=0.405)$ (Table 3$)$.

\section{DISCUSSION}

TIVA is a technique using a combination of sedatives, hypnotics, opioids, and muscle relaxants as an intravenous infusion in patients ventilated with a mixture of oxygen and air. ${ }^{[8]}$

Many side effects that arise from inhalation anesthesia, such as contamination of the operating room atmosphere and postoperative nausea and vomiting, are not observed in TIVA applications. ${ }^{[9,10]}$ Properties of iv anesthetic agents suitable for continuous infusion include water-solubility, a 
Table 3. Intergroup variations in recovery parameters

\begin{tabular}{lccc}
\hline & Group P & Group D & p-value \\
\hline Time to onset of spontaneous respiration $(\mathrm{min})$ & $3.9 \pm 0.9$ & $4.1 \pm 0.6$ & 0.207 \\
Time to opening eyes (min) & $5.2 \pm 1.2$ & $5.3 \pm 0.8$ & 0.669 \\
Time to compliance with verbal commands (min) & $5.4 \pm 0.8$ & $5.9 \pm 0.7$ & 0.06 \\
Aldrete score at 0 min & $7.2 \pm 0.7$ & $7.1 \pm 0.6$ & 0.800 \\
Aldrete score at 5 min & $8.4 \pm 0.5$ & $8.4 \pm 0.6$ & 0.565 \\
Aldrete score at 30 min & $9.6 \pm 0.4$ & $9.7 \pm 0.4$ & 0.409 \\
Number of patients with an Aldrete score of 10 points at the end of 30 minutes & $19(63.3 \%)$ & $22(73.3 \%)$ & 0.405 \\
Time to extubation $(\mathrm{min})$ & $4.9 \pm 1.0$ & $5.4 \pm 0.8$ & $0.02^{*}$ \\
\hline${ }_{p}<0.05$ significant. & & &
\end{tabular}

low side effect profile, affordability, rapid onset, and recovery without accumulation of the drug. ${ }^{[1]}$

Propofol and remifentanil are the most suitable agents for a continuous infusion that combine all of these features. ${ }^{[12-14]}$

Propofol has pharmacokinetic properties suitable for dual and triple compartment models. In young, non-premedicated patients, propofol alone provided sufficient loss of consciousness at a dose of Cp 5-6 $\mu \mathrm{gL} \mathrm{m}^{-1}$. In premedicated patients or when an opioid or nitrous oxide was administered in addition to propofol, a Cp of 4-5 $\mu \mathrm{g} \mathrm{mL}-1$ has been reported. ${ }^{[15,16]}$ When propofol was administered alone using the Schnider model, an effect-site concentration (Ce) for unconsciousness of $2.9 \mathrm{\mu g} \mathrm{ml}^{-1}$ has been reported. When used together with remifentanil at doses of

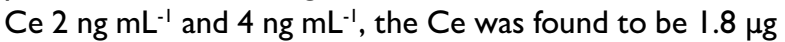

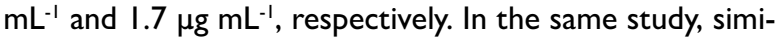
lar maintenance remifentanil and propofol Ce values were indicated, whereas a $\mathrm{Ce}$ value of $4.1 \mu \mathrm{g} \mathrm{mL} \mathrm{L}^{-1}$ was reported when propofol was used alone. ${ }^{[17]}$

In addition to the Marsh and Schnider models used for propofol in TCl, the Scott, Gepts, and Minto pharmacokinetic models have been established for alfentanil, sufentanil, and remifentanil, respectively. ${ }^{[18,19]}$

A Ce 4-4.5 $\mathrm{ng} \mathrm{mL}^{-1}$ dose of remifentanil is used together with propofol provides an adequate level of analgesia and hemodynamic stability, while Ce $1.5-6 \mathrm{ng} \mathrm{mL^{-1 }}$ doses are sufficient for induction and tracheal intubation. ${ }^{[20-22]}$

The $\mathrm{TCl}$ method provides better hemodynamic stability and allows for a faster recovery compared with manually adjusted, total intravenous anesthesia. ${ }^{[23]}$

De Castro et al. ${ }^{[24]}$ used $3 \mu \mathrm{g} \mathrm{kg-1}$ propofol with the $\mathrm{TCl}$ method in addition to a manual infusion $\left(0.25 \mu \mathrm{g} \mathrm{kg}{ }^{-1} \mathrm{~min}-\mathrm{I}\right)$ of remifentanil in one group undergoing carotid surgery and propofol followed by remifentanil $\mathrm{TCl}$ in another group ( $4 \mathrm{ng} \mathrm{mL}^{-1}$ ). They reported that the hemodynamics were more stable and that the remifentanil use was lower in the $\mathrm{TCl}$ group.

In our study, remifentanil (3 $\left.\mathrm{ng} \mathrm{mL}^{-1}\right)$ with Propofol (4 $\left.\mu \mathrm{g} \mathrm{mL}^{-1}\right)$, or remifentanil $\left(3 \mathrm{ng} \mathrm{mL^{-1 }}\right)$ with $6 \%$ desflurane were used with Injectomat TIVA TCI device. The Schnider model was used for propofol and the Minto model for remifentanil. $\mathrm{TCl}$ was used to administer remifentanil in both groups and good hemodynamic stability was achieved. There was no significant difference between the two study groups concerning recovery characteristics other than extubation time.

The depth of anesthesia was monitored using BIS during a study examining septorhinoplasty operations administering propofol $\left(3 \mu \mathrm{g} \mathrm{kg}^{-1}\right)$ together with remifentanil (I

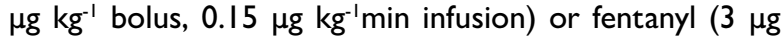
$\mathrm{kg}^{-1}$ bolus, $0.03 \mu \mathrm{kg}^{-1}$ min infusion) delivered by manual infusion. While the recovery from anesthesia was faster with remifentanil use, it was also clinically acceptable with fentanyl. Although the time-dependent half-life of fentanyl is longer due to its cumulative effect, it has been reported that it can be administered safely in appropriate cases by adjusting the time-dose relationship. ${ }^{[25]}$

In another study, remifentanil ( $\left.3 \mathrm{ng} \mathrm{mL}^{-1}\right)$ and propofol (4 $\left.\mu \mathrm{g} \mathrm{mL}^{-1}\right)$ or $6 \%$ desflurane were used in patients whose depth of anesthesia was followed using BIS during earnose-throat operations, and rapid induction of anesthesia, intraoperative hemodynamic stability and faster recovery from anesthesia were observed in both group. The lower blood pressure measured in the desflurane and remifentanil group has been reported as an advantage in this type of operation due to the reduced risk of bleeding. ${ }^{26]}$

Remifentanil has also been used with propofol to provide sedation during oocyte retrieval, and $1.5-2 \mathrm{ng} \mathrm{mL}^{-1}$ concentrations of remifentanil were found to be superior to $2.5 \mathrm{ng} \mathrm{mL} \mathrm{mL}^{-1}$ in terms of early recovery. ${ }^{[27]}$

In our study, remifentanil ( $3 \mathrm{ng} \mathrm{mL}^{-1}$ ) and propofol (4 $\mathrm{\mu g}$ $\mathrm{mL}^{-1}$ ) or $6 \%$ desflurane were used with a TCl device. Similar to the study performed by Mahli et al., ${ }^{[26]}$ perioperative hemodynamic stability was achieved in both groups; however, the MAP, (heart rate) HR, and (diastolic arterial pressure) DAP were significantly lower in the desflurane and remifentanil group. There was no difference between groups in terms of time to onset of spontaneous respiration, eye-opening, compliance with verbal commands, or Aldrete recovery score. The extubation time was shorter in the propofol and remifentanil groups.

Liu et al. ${ }^{[28]}$ examined the effects of BIS monitoring in ambulatory surgery. They found that the use of anesthetics 
with BIS monitorization decreased by $19 \%$ in standard clinical practice and that the incidence of postoperative nausea and vomiting also decreased. In the same study, it was observed that the duration of stay in the recovery room after anesthesia had been reduced.

In the same study, it was emphasized that the use of BIS provided quantification of the depth of anesthesia and titration of the hypnotic effects of general anesthetic drugs. ${ }^{[28]}$

In our study, the Quatro sensor electrode was placed on the forehead and the depth of anesthesia was monitored to maintain a BIS value between 40-60 using the Aspect electroencephalogram monitor. Good hemodynamic stability was achieved in both groups. BIS-guided combinations of both propofol-remifentanil and desfluraneremifentanil with $\mathrm{TCl}$ were suitable for patients undergoing lower abdominal surgery. The low blood pressure achieved with remifentanil and desflurane may confer an important advantage.

Ethics Committee Approval

Approved by the local ethics committee (decision no: 2018/5I4/I28/I5, date: 24.4.2018).

Informed Consent

Prospective study.

Peer-review

Internally peer-reviewed.

Authorship Contributions

Concept: Ö.S.; Design: Ö.S.; Supervision: G.A.; Fundings: Ö.S., G.A.; Materials: Ö.S., G.A.; Data: Ö.S.; Analysis: Ö.S.; Literature search: Ö.S., G.A.; Writing: Ö.S.; Critical revision: Ö.S., G.A.

Conflict of Interest

None declared.

\section{REFERENCES}

1. Target controlled infusion (TCI) in anaesthetic practice. Sweeden, Astra Zeneca Neuroscience 2004;1-64.

2. Absolom AR, Struys MRF. An overview of TCI and TIVA. 2nd ed. Gent: Academia Press; 2007.p. 1-108.

3. Cazalad JB, Levron JC, Servin F. Anesthetic agents using in TCI. 2nd ed. Sauveur: Fresenius Kabi; 2009. p. 1-105.

4. Glass PS, Shafer SL, Reves JG. Intravenous drug delivery systems. In: Miller RD, editor. Anesthesia. 5th ed. New-York: Churchil Livingstone; 2000. p. 377-411.

5. van den Nieuwenhuyzen MC, Engbers FH, Vuyk J, Burm AG. Target-controlled infusion systems: role in anaesthesia and analgesia. Clin Pharmacokinet 2000;38:181-90. [CrossRef]

6. Guarracino F, Lapolla F, Cariello C, Danella A, Doroni L, Baldassarri R, et al. Target controlled infusion: TCI. Minerva Anestesiol 2005;71:335-7.

7. https://www.randomizer.org/ Available online date: 10.06.2020.

8. Kayhan Z. Klinik Anestezi. 2nd ed. İstanbul: Logos Yayıncilk; 1997. p. 59-60,177-92, 378-83.

9. Nightingale JJ, Lewis IH. Recovery from day-case anaesthesia: comparison of total i.v. anaesthesia using propofol with an inhalation technique. Br J Anaesth 1992;68:356-9. [CrossRef]
10. Raftery S, Sherry E. Total intravenous anaesthesia with propofol and alfentanil protects against postoperative nausea and vomiting. Can J Anaesth 1992;39:37-40. [CrossRef]

11. Miller DR. Intravenous infusion anaesthesia and delivery devices. Can J Anaesth 1994;41:639-52. [CrossRef]

12. Vuyk J, Mertens MJ, Olofsen E, Burm AG, Bovill JG. Propofol anesthesia and rational opioid selection: determination of optimal EC50EC95 propofol-opioid concentrations that assure adequate anesthesia and a rapid return of consciousness. Anesthesiology 1997;87:154962. [CrossRef]

13. Lysakowski C, Dumont L, Pellegrini M, Clergue F, Tassonyi E. Effects of fentanyl, alfentanil, remifentanil and sufentanil on loss of consciousness and bispectral index during propofol induction of anaesthesia. Br J Anaesth 2001;86:523-7. [CrossRef]

14. Sarıkaya HG, Dinçer E, Özgültekin A, Turan G, Turan F. Comparison of the remifentanil and remifentanil+propofol combination for sedoanalgesia in functional endoscopic sinus surgery. J Kartal TR 2011;22:1-6. [CrossRef]

15. Struys M, Versichelen L, Rolly G. Influence of pre-anaesthetic medication on target propofol concentration using a 'Diprifusor' TCI system during ambulatory surgery. Anaesthesia 1998;53:68-71. [CrossRef]

16. Servin FS, Marchand-Maillet F, Desmonts JM. Influence of analgesic supplementation on the target propofol concentrations for anaesthesia with 'Diprifusor' TCI. Anaesthesia 1998;53:72-6. [CrossRef]

17. Struys MM, Vereecke H, Moerman A, Jensen EW, Verhaeghen D, De Neve N, et al. Ability of the bispectral index, autoregressive modelling with exogenous input-derived auditory evoked potentials, and predicted propofol concentrations to measure patient responsiveness during anesthesia with propofol and remifentanil. Anesthesiology 2003;99:802-12. [CrossRef]

18. Scott JC, Stanski DR. Decreased fentanyl and alfentanil dose requirements with age. A simultaneous pharmacokinetic and pharmacodynamic evaluation.J Pharmacol Exp Ther 1987;240:159-66. [CrossRef]

19. Shafer SL, Varvel JR. Pharmacokinetics, pharmacodynamics, and rational opioid selection. Anesthesiology 1991;74:53-63. [CrossRef]

20. Høymork SC, Raeder J, Grimsmo B, Steen PA. Bispectral index, predicted and measured drug levels of target-controlled infusions of remifentanil and propofol during laparoscopic cholecystectomy and emergence. Acta Anaesthesiol Scand 2000;44:1138-44. [CrossRef]

21. Röpcke H, Könen-Bergmann M, Cuhls M, Bouillon T, Hoeft A. Propofol and remifentanil pharmacodynamic interaction during orthopedic surgical procedures as measured by effects on bispectral index. J Clin Anesth 2001;13:198-207. [CrossRef]

22. Hans P, Bonhomme V, Born JD, Maertens de Noordhoudt A, Brichant JF, et al. Target-controlled infusion of propofol and remifentanil combined with bispectral index monitoring for awake craniotomy. Anaesthesia 2000;55:255-9. [CrossRef]

23. Passot S, Servin F, Allary R, Pascal J, Prades JM, Auboyer C, et al. Target-controlled versus manually-controlled infusion of propofol for direct laryngoscopy and bronchoscopy. Anesth Analg 2002;94:1212-6.

24. De Castro V, Godet G, Mencia G, Raux M, Coriat P. Target-controlled infusion for remifentanil in vascular patients improves hemodynamics and decreases remifentanil requirement. Anesth Analg 2003;96:33-8. [CrossRef]

25. Coskun D, Celebi H, Karaca G, Karabiyik L. Remifentanil versus fentanyl compared in a target-controlled infusion of propofol anesthesia: quality of anesthesia and recovery profile. J Anesth 2010;24:373-9.

26. Mahli A, Coskun D, Karaca GI, Akcali DT, Karabiyik L, Karadenizli Y. Target-controlled infusion of remifentanil with propofol or desflurane under bispectral index guidance: quality of anesthesia and recovery profile. J Res Med Sci 2011;16:611-20.

27. Coskun D, Gunaydin B, Tas A, Inan G, Celebi H, Kaya K. A com- 
parison of three different target-controlled remifentanil infusion rates during target-controlled propofol infusion for oocyte retrieval. Clinics (Sao Paulo) 2011;66:811-5. [CrossRef]
28. Liu SS. Effects of Bispectral Index monitoring on ambulatory anesthesia: a meta-analysis of randomized controlled trials and a cost analysis. Anesthesiology 2004;101:311-5. [CrossRef]

\section{Hedef Kontrollü Infüzyonda Propofol-Remifentanil ve Desfluran-Remifentanilin Karşılaştırlması}

Amaç: Alt karın cerrahisi sırasında bisektral indeks (BIS) rehberliğinde hedef kontollü infüzyon (HKi) kullanılarak iki anestezik rejimin, propofolremifentanil veya desfluran-remifentanilin klinik özelliklerini incelemektir.

Gereç ve Yöntem: Alt karın cerrahisi geçirecek 60 hasta randomize olarak iki gruba ayrıldı: Propofol-remifentanil grup (Grup P) ve desfluran-remifentanil grup (Grup D). Tüm hastalara anestezi indüksiyonu $2 \mathrm{mg} \mathrm{kg}^{-1}$ propofol, I $\mu \mathrm{kg}^{-1}$ remifentanil ve $0.6 \mathrm{mg} \mathrm{kg}^{-1}$ rokuronyum iv ile sağlandı. Her iki grupta da entübasyon sonrası remifentanil infüzyonu Minto farmokinetik modeline göre HKI cihazıyla uygulandı. Grup D'deki hastalara \%50-50 oksijen hava karışımı ve \%6 desflurane uygulandı. Grup P'de propofol \% I ( I0 mg/mL) için farmakokinetik model Schnider modeli seçildi ve HKi ile $4 \mu / \mathrm{mL}^{-1}$ olacak şekilde uygulandı. BIS değeri 40-60 arasında tutulacak şekilde dozlar artıııldı ya da azaltıldı. Tüm hastaların hemodinamik parametreleri, spontan solunumun geri dönme süresi, göz açma süresi, trakeal ekstübasyon süresi, verbal komutlara uyma süresi, anestezi ve cerrahi süresi, ameliyat sonrası Modifiye Aldrete skoru kaydedildi.

Bulgular: Operasyon süresince yapılan incelemede kalp atım hızı $(p=0.006)$, diyastolik arter basıncının $(p=0.003)$ ve ortalama arter basıncının $(p<0.000$ I) Grup P'de anlamlı düzeyde Grup D'den daha yüksek seyrettiği görüldü. Ekstübasyon süresi Grup P'de ( $p=0.02)$ daha kısa iken, diğer derlenme bulguları açısından iki grup arasında fark yoktu.

Sonuç: Hedef kontollü infüzyon ile hem propofol-remifentanilin hem de desfluran-remifentanilin bispektral indeks kılavuzlu kombinasyonları alt karın cerrahisi geçiren hastalar için uygundur. Desfluran ve HKi ile remifentanil deki düşük kan basıncı önemli bir avantaj olabilir.

Anahtar Sözcükler: Bispectral indeks; desflurane; hedef kontrollü infüzyon; propofol; remifentanil. 